\title{
Is there a pattern for innovative firms? A case study from a Portuguese and a Polish Region
}

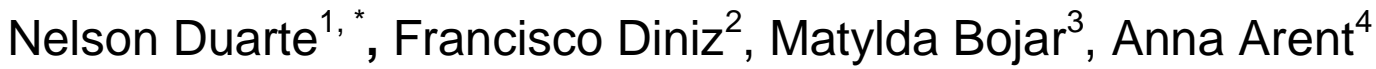 \\ ${ }^{1}$ School of Management and Technology of Felgueiras, Polytechnic of Porto, CIICESI, CETRAD, \\ Portugal \\ ${ }^{2}$ CETRAD, Vila Real, Portugal \\ ${ }^{3,4}$ Faculty of Management - Lublin University of Technology, Poland \\ *nduarte@estgf.ipp.pt
}

\begin{abstract}
The article presents the results of the study and comparison of innovation of Portuguese and Polish companies. For this research, the perspective is taken from innovation based in intangible factors, trying to measure, above all, the organizational culture of companies on innovation. The results state that Portuguese firms are less innovative than Polish ones. At the same time, in both countries manufacturing companies are more innovative than companies in the construction sector. In the case of Polish companies it was demonstrated that there was a relationship between the size and age of the innovation. The research results will be used to assess the culture of enterprises' innovation in other countries.
\end{abstract}

Keywords: Innovation, Strategies, Intrapreneurship, Portugal, Poland

\section{Introduction}

Innovation is a critical ingredient in today's economy. The main purpose of this paper is to compare two European regions (Tâmega e Sousa from Portugal, and Lublin from Poland) in terms of innovation propensity. The study focus on the micro-level, i.e, it is not intended to study the regional level of innovation, but the level of innovation adopted by firms within those regions. For that purpose were selected SMEs acting at the manufacturing and construction sectors operating in both regions. Once identified and compared the innovation level in both regions, we will try to identify an innovation pattern in these regions.

Among academic and political world, innovation is still a concept frequently referred. However, is not easy to find a general definition for this concept [1]. Innovation is a concept that crosses many different areas. From technology to regional or national innovation, the concept is always present. In this work it is not intended to discuss the definition of innovation, but there are some important references that were taken into consideration. In first place the Oslo Manual [2] that identifies four main types of innovation: Product, Process, Marketing and Organizational. Secondly the concepts of regional innovation systems, firstly driven by international competition [3]. Also important are the concepts of entrepreneurship and intrapreneurship [4].

Innovation is a concept that is also strongly connected to the concept of entrepreneurship. In fact, entrepreneurship is a combination of innovation, risk and proactivity [5]. Typically it is related to firm's external behaviour. But since 1985 the concept of entrepreneurship is also regarded as something internal - intrapreneurship [4]. This means that entrepreneurship must also occur within an established firm. This behaviour must be part of the organizational culture, but, above all, it should emanate from firm management.

According to Carree et. al. [6] entrepreneurship can be seen through the creation of new businesses, while intrapreneurship in the form of new ideas and responsibilities implemented in organizations. Both are assumed to be essential for the creation of new economic activity. Both concepts are important to clarify the approach of innovation that was adopted under the present research - analysis of innovative strategies, as it will be presented later on.

As previously and briefly mentioned the definition of innovation is not clear. Not only the definition can vary widely, but also the way of measuring it. Innovation can be measured through metrics, KPIs, 
enablers, activities and outputs, among others. However, the measurements vary along firms, studies or institutions. "One of the reasons that only about 1/3 of all Fortune 1000 companies have formal innovation metrics is because this simple question (how to measure?) does not have a simple answer" [7].

Moving from the micro level (firms) to a global approach it is also possible to realize that the framework to measure innovation is different from the Innovation Union Scoreboard (IUS) 2015 [8] and the Global Innovation Index (GII) 2015 [9]. According to the IUS 2015 [8], both Portugal and Poland are classified as moderate innovators, however Poland is behind Portugal. A similar scenario occurs at GII where Portugal takes the position 62 in the ranking, while Poland the position 93.

This brief overview allows to conclude that innovation can be approached from many different perspectives. In fact, the strategic intent of innovation can vary wildly according to the definition source. Even the type of innovation claimed to be important for regional growth varies according to author's perspective. While some authors still consider technological innovation as the major driving force behind economic growth and prosperity [10], some others argue that "non-technological innovation is becoming increasingly recognized as a previously overlooked factor with a strong potential to contribute to organizational performance" [11]. Some authors argue that regional growth should be first supported by public policies on innovation for SMEs [12], while some others argue that "if only risk capital is injected, it flows straight to low-quality entrepreneurship" [13], thus low quality innovation strategies. Other intangibles should be accompanied by risk capital (access to novel ideas, role models, informal forums, region-specific opportunities, safety nets, access to large markets and executive leadership) [13].

The relation between intangible factors and innovation has not been explored in the literature. There are a few attempts on this field [14]-[16] that identify some important factors such as Organizational, Social and Network Capital, Cooperation.

By focusing on the intangible factors, and arguing that innovation does not occur by governmental law (recognizing however the importance of governmental support), the authors of this paper assumed for the purpose of this research that "Sustained Innovation is the state attained by organizations that have built a "culture of innovation," capable of innovating at every point of the compass - a full 360 degrees of innovation - in all aspects of the business - management, operations, customers, suppliers, and among every team." [17]

In brief, and in order to frame the approach to innovation that was taken to develop our research, firm innovation is regarded as a result from intangible factors, organized according to the types of innovation identified by the Oslo Manual [2] (Product, Process, Marketing and Innovation) and supported and tested by the Community Innovation Survey. "The survey covers areas such as new or significantly improved goods or services, and the introduction of new or significantly improved processes, logistics or distribution methods. It also gives information on the characteristics of innovation activity at the enterprise level, thereby creating a better understanding of the innovation process and the effects of innovation on the economy" [18].

Bearing in mind these main guidelines, further researches were taken in order to identify the main factors/strategies that a firm can take in order to be considered an innovative firm. On the results section the factors are listed in Table 2. Since innovation is being analysed through strategies adopted, it means that we adopted a management perspective. Thus the concept is being analysed under the Intrapreneurship perspective.

In the next section we will find a description from the region under analysis, followed by an explanation of the research methodology adopted.

\section{The Regions}

The study was carried out in two European regions: Tâmega e Sousa, in Portugal, and Lubelskie Voivodeship in Poland. 
The region of Tâmega $e$ Sousa is composed of 11 Concelhos ${ }^{1}$ composing the inter-municipal community of Tâmega e Sousa. This community is one of seven inter-municipal entities (groups of Concelhos organized as administrative regions) in the Northern Region of Portugal.

From Poland data was collected from Lubelskie Voivodeship, which is located in eastern part of Poland. Despite the large area, it is one of the least populated and urbanized regions in Poland. Lubelskie Voivodeship is situated on the eastern EU border with Ukraine and Belarus.

In order to get a brief overview of both regions in Table 1 are presented some elements characterizing both regions:

Table 1. Some elements from Portugal and Poland

\begin{tabular}{|c|c|c|}
\hline & Portugal (Tâmega e Sousa) & Poland (Lubelskie Voivodeship) \\
\hline Area $\left(\mathrm{Km}^{2}\right)$ & 1,830 & 25,122 \\
\hline $\begin{array}{l}\text { Number of sub regions } \\
\text { within the region }\end{array}$ & $\begin{array}{c}\text { Belongs to a NUTS } 3 \\
\text { Amarante, Baião, Castelo de } \\
\text { Paiva, Celorico de Basto, Cinfães, } \\
\text { Felgueiras, Lousada, Marco de } \\
\text { Canaveses, Paços de Ferreira, } \\
\text { Pensafiel, Resende }\end{array}$ & $\begin{array}{l}\text { Region (NUTS 2): Lublin } \\
\text { Voivodsip, } 4 \text { subregions } \\
\text { (NUTS3) Bialski, Chełmsko- } \\
\text { Zamojski, Lubelski, Puławski }\end{array}$ \\
\hline Population & 434,165 & $2,126,310$ \\
\hline Number of Firms (total) & $26,500(2012)$ & $173,200(2015)$ \\
\hline $\begin{array}{l}\text { Number of Firms in } \\
\text { manufacturing and } \\
\text { construction }\end{array}$ & $\begin{array}{c}\text { Manufacturing: } 4,399 \\
\text { Construction: } 3,754\end{array}$ & $\begin{array}{l}\text { Manufacturing: } 13,856 \\
\text { Construction: } 20,784\end{array}$ \\
\hline GDP & $\begin{array}{c}4,397 \text { million Euro (2014) } \\
2,5 \% \text { of total in Portugal }\end{array}$ & $\begin{array}{c}16,062 \text { million Euro (2014) } \\
3,9 \% \text { of total in Poland }\end{array}$ \\
\hline $\begin{array}{l}\text { Employment in } \\
\text { manufacturing and } \\
\text { construction }\end{array}$ & $\begin{array}{c}\text { Manufacturing: } 53,783 \\
\text { Construction: } 32,685 \\
\text { (2011) } \\
50 \% \text { of total employment }\end{array}$ & $\begin{array}{c}\text { Manufacturing: } 105,510 \\
\text { Construction: } 34,089 \\
\text { (2015) } \\
17,2 \% \text { of total employment }\end{array}$ \\
\hline Other relevant elements & $\begin{array}{l}\text { - Industrial district: Shoes making } \\
\text { in Felgueiras; Textile in Lousada; } \\
\text { Wood furniture in Paços de } \\
\text { Ferreira, and in metalworking in } \\
\text { Amarante; } \\
\text { - One of the least developed } \\
\text { regions in Portugal }\end{array}$ & $\begin{array}{c}\text { - The largest and most important } \\
\text { agricultural region of Poland } \\
\text { - Important industries: } \\
\text { Agro-Industry, mining, furniture, } \\
\text { aviation } \\
\text {-One of the least developed } \\
\text { regions in Poland }\end{array}$ \\
\hline
\end{tabular}

From Table 1 it possible to identify some difference between the regions, but at the same time some similarities such as regions lagging behind within country development.

\section{Methodology}

\subsection{The Questionnaire}

The main purpose of the study, carried out in 2013/2014, in the manufacturing and construction sectors of Lublin (Poland) and Tâmega e Sousa (Portugal) was the characterization of these regions relatively to entrepreneurship and local sustainability. In order to measure innovation (as an element to measure entrepreneurship later on) under a managerial perspective (intrapreneurship) were identified 11 main factors according to Table 2.

\footnotetext{
${ }^{1}$ Concelho: Portuguese administrative unit divided into smaller units called freguesias.
} 
Table 2. Innovation Strategies

\begin{tabular}{|l|l|}
\hline Strategies (intangible factor) & Type of innovation \\
\hline Investment in new equipment or production methods & Process \\
\hline Productive process reorganization & Process \\
\hline Sales extension for new markets & Marketing \\
\hline Product/service differentiation & Product \\
\hline New commercialization/marketing methods were used & Marketing \\
\hline New products & Product \\
\hline Focus change from production to marketing & Organizational/Marketing \\
\hline Firm/Management reorganization & Organizational \\
\hline Cooperation (competitors, or suppliers or customers) & Organizational \\
\hline Social responsibility & Organizational/Marketing \\
\hline Firm's image investments & Marketing \\
\hline Others & Any one, within these 4 types \\
\hline
\end{tabular}

As previously referred the strategies presented above aimed to measure the levels of innovation within firm management. The project did not aim to measure external factors of innovation, such as $R \& D$ investment, patents, or number of ideas. The main purpose is to identify to what extent firms develop an organizational culture that welcomes innovation strategies in their daily management. The strategies were regarded as the intangible factors of innovation, in order to get information about firm's regular activities that could lead the firm into one level of innovation.

According to the strategies presented at Table 2, a firm could score for 12 points. Firms classification were defined first into 5 classes, but the analysis relied into 3 classes presented on Table 3

In order to analyse the results, the following working hypotheses have been put forward:

$\mathrm{H}_{1}$ : Portuguese and Polish firms present different behaviours in terms of innovation strategies.

$\mathrm{H}_{2}$ : Are firms operating in manufacturing more innovative than those operating in construction?

$\mathrm{H}_{3}$ : Are larger firms more innovative?

$\mathrm{H}_{4}$ : Is there a relation between innovation and age (firm and manager)?

$\mathrm{H}_{5}$ : Are familiar firms more innovative?

$\mathrm{H}_{6}$ : Are innovative firms more sustainable?

$\mathrm{H}_{7}$ : Are innovative firms more risk takers or proactive?

\subsection{Sample Calculations}

The study was focused on a valid sample. In order to find the minimum sample size it was necessary to define:

- Confidence level;

- Error margin;

- Proportion of answers obtained in a particular section.

It was also developed a pilot study with 35 observations in Poland and 33 Portugal in order to analyse the proportion of answers that occur relatively to the degree of innovation. From this initial sample it was possible to do some inferences to the final sample, using the following formula [19]:

$$
n=p \% * q \% *(z / e \%)^{2}
$$

where: $n$ : minimum sample size required;

$p \%$ : proportion belonging to the specified category;

$q \%$ : proportion not belonging to the specified category;

$z: \mathrm{z}$ value corresponding to the level of confidence required:

$e$ : margin of error required; 
According to the final results it was necessary to get 158 answers in Poland, and less than that in Portugal, since we got just $8.5 \%$ of moderate innovative firms. These results were calculated for a $95 \%$ interval confidence. The final analysis included 283 questionnaires in Portugal, and 311 in Poland.

\section{Results}

The first results to be presented are related to the levels of innovation by country:

Table 3. Frequencies on levels of innovation

\begin{tabular}{|l|c|c|c|}
\hline \multirow{2}{*}{} & \multicolumn{3}{|c|}{$\%$} \\
\cline { 2 - 4 } & Total & Portugal & Poland \\
\hline Innovation Averse & 69.7 & 91.5 & 49.8 \\
\hline Moderate Approach to Innovation & 24.2 & 8.5 & 38.6 \\
\hline Innovative Firm & 6.1 & & 11.6 \\
\hline
\end{tabular}

Analysing Table 3 it is possible to identify some differences between both countries, but are these differences statistically valid? In order to analyse a relation between variables (variable association), were performed some cross tabulations based on the following hypothesis:

$\mathrm{H}_{0}$ : The variables are independent (do not exists variable association) vs.

$\mathrm{H}_{1}$ : The variables are dependent (exist association)

To analyse these hypothesis, according to the literature we must run a $\chi^{2}$ test. The decision will be taken according to the $p$ value obtained with the $\chi^{2}$ test.

The first variable dependence test was related with innovation and countries. In a first attempt it was verified that the $\mathrm{p}$-value for the $\chi^{2}$ was lower than 0.01 , which means that it is possible to reject $\mathrm{H}_{0}$ (variable independence) with $99 \%$ of confidence. In practical terms it means that Polish firms are more innovative than Portuguese ones.

Since it was identified a difference between both countries the tests to be performed from now on should be performed by country and not as a whole.

Considering the relation between innovation and the activity sector the statistical tests allowed to conclude, with $95 \%$ of confidence, that in both countries $\mathrm{H}_{0}$ can be rejected. This means that in both countries, industry is more innovative than construction.

On what regards innovation and firm size, is not possible to reject $\mathrm{H}_{0}$ for Portuguese data. For Poland, it is possible to reject $\mathrm{H}_{0}$, but with a confidence level of $90 \%$. It means that is possible to identify a pattern of a higher propensity to innovation by larger firms.

It was also tested a possible relation between firm age and the innovation levels. In both countries it was not possible to reject $\mathrm{H}_{0}$. According to the results does not exist a pattern on firms' age that make the firm more or less innovative. Following Schumpeter on the theory that people are more innovative up to 35 years old [20], it was also performed a test in order to identify a relation between an innovative pattern and age. Due to the identification questions the test did not considered people up to 39. In Portugal was not possible to get a conclusion, since $\mathrm{H}_{0}$ was not rejected. In Poland it was possible to reject $\mathrm{H}_{0}$ (confidence level of $90 \%$ ). In this case, it was identified a pattern: younger people present a higher tendency to innovation.

No relation was found $\left(\mathrm{H}_{0}\right.$ rejected $)$ between innovation propensity and the familiar classification of firms.

Considering the relation between innovation and sustainability it was not possible to get any conclusion. In Portugal the statistical assumption were not fulfilled in order to perform the test. Concerning Polish data it was not possible to reject $\mathrm{H}_{0}$.

Getting into the concepts of entrepreneurship (Innovation, Risk and Proactivity) since these strategies were measured independently it was also tested a possible relation innovation - risk, and innovation proactivity 
Regarding risk, in Portugal is not possible to get statistical valid results because assumptions were not fulfilled. However it was noticed that such as at innovation where were identified just to classes of innovation (averse and moderate) the same was verified at risk (there are no firms with a risk propensity behaviour, at most there are some firms with a moderate approach to risk). Even without statistical valid results it was identified that firms in Portugal do not present an innovative neither risk behaviour. By looking to the polish results it was possible to reject $\mathrm{H}_{0}$ with a confidence level of $99 \%$ and to conclude that firms with an innovative behaviour are those that present a higher propensity to adopt risk strategies.

Analysing the relation between innovation and proactivity it was possible to reject $\mathrm{H}_{0}$ in both countries and to verify that firms with a lower propensity to innovation are normally more reactive and less proactive firms.

\section{Conclusion}

After results presentation as conclusion it is possible to present a table summing up the main conclusions:

Table 4. Main Conclusions (Comparative Table)

\begin{tabular}{|l|l|l|}
\hline & \multicolumn{1}{|c|}{ Portugal } & \multicolumn{1}{c|}{ Poland } \\
\hline $\mathrm{H}_{1}$ : Countries Differences & \multicolumn{1}{|c|}{ Polish firms are more innovative } \\
\hline $\mathrm{H}_{2}:$ Sectors Differences & Industry is more innovative & Industry is more innovative \\
\hline $\mathrm{H}_{3}:$ Innovation and firm size & No conclusion & Larger are more innovative \\
\hline $\mathrm{H}_{4}:$ Innovation and age & No relation & $\begin{array}{l}\text { Younger managers are more } \\
\text { innovative }\end{array}$ \\
\hline $\begin{array}{l}\mathrm{H}_{5}: \text { Innovation and familiar } \\
\text { businesses }\end{array}$ & No conclusion & No conclusion \\
\hline $\mathrm{H}_{6}:$ Innovation and Sustainability & No conclusion & No relation \\
\hline $\mathrm{H}_{7}:$ Innovation and Risk & $\begin{array}{l}\text { Neither innovative nor risk } \\
\text { takers }\end{array}$ & Innovative are risk takers \\
\hline $\mathrm{H}_{7}:$ Innovation and Proactivity & Innovative are Proactive & Innovative are Proactive \\
\hline
\end{tabular}

The results state that Portuguese firms are less innovative than Polish ones, and this result may lead most of the conclusion. It was verified that in Portugal there are no firms classified as innovators. At most Portuguese firms are moderate innovators. This result is not in accordance to the IUS and GII, where Portugal is presented as more innovator than Poland. However, we may conclude that under different frameworks, the results are different. For this research, we adopted a perspective of innovation based in intangible factors, trying to measure, above all, the organizational culture of firms on innovation.

For future research it is expected to analyse different issues such as local integration levels, internationalization, or other issues related to organizational culture. This paper is the first outcome from a research that will allow to explore innovation and to find elements to characterize firms with an innovative culture. For that results from other countries will also be included in future research.

\section{References}

[1] Information from http://knowledge.wharton.upenn.edu/article/why-innovation-is-tough-to-defi ne-and-even-tougher-to-cultivate/.

[2] OECD, "Oslo Manual Guidelines For Collecting and Interpreting Innovation in Communities," OECD Publishing, (2005)

[3] D. Doloreux and S. Parto, "Regional innovation systems: Current discourse and unresolved issues," Technol. Soc., vol. 27, no. 2, pp. 133-153, (2005) 
[4] G. Pinchot, Intrapreneuring: Why You Don't Have to Leave the Corporation to Become an Entrepreneur. (1985)

[5] D. Miller, "The Correlates of Entrepreneurship in Three Types of Firms," Manage. Sci., vol. 29, no. 7, pp. 770-791, (1983)

[6] M. Carree, A. Van Stel, R. Thurik, and S. Wennekers, "Economic development and business ownership: An analysis using data of 23 OECD countries in the period 1976-1996," Small Bus. Econ., vol. 19, no. 3, pp. 271-290, (2002)

[7] Information from http://www.innovation-point.com/innovationmetrics.htm.

[8] European Union, "Innovation Union Scoreboard 2015," (2015)

[9] Cornell University; INSEAD; WIPO, "Global Innovation Index 2015 - Effective Innovation Policies for Development," Geneva, (2015)

[10] M. S. A. Eshtehardi, S. K. Bagheri, and A. Di Minin, "Regional innovative behavior: Evidence from Iran," Technol. Forecast. Soc. Change, in proof, (2016)

[11] M. Černe, R. Kaše, and M. Škerlavaj, "Non-technological innovation research: evaluating the intellectual structure and prospects of an emerging field," Scand. J. Manag., vol. 32, no. 2, pp. 69-85, (2016)

[12] S. Doh and B. Kim, "Government support for SME innovations in the regional industries: The case of government financial support program in South Korea," Res. Policy, vol. 43, no. 9, pp. 1557-1569, (2014)

[13] S. Venkataraman, "Regional transformation through technological entrepreneurship," J. Bus. Ventur., vol. 19, no. 1, pp. 153-167, (2004)

[14] J. P. Kramer, E. Marinelli, S. Iammarino, and J. R. Diez, "Intangible assets as drivers of innovation: Empirical evidence on multinational enterprises in German and UK regional systems of innovation," Technovation, vol. 31, no. 9, pp. 447-458, (2011)

[15]R. Rutten and F. Boekema, "Regional social capital: Embeddedness, innovation networks and regional economic development," Technol. Forecast. Soc. Change, vol. 74, no. 9, pp. 1834-1846, (2007)

[16]Á. R. Vásquez-Urriago, A. Barge-Gil, and A. Modrego Rico, "Science and Technology Parks and cooperation for innovation: Empirical evidence from Spain," Res. Policy, vol. 45, no. 1, pp. 137-147, (2016)

[17] Information from www.fastcompany.com/3015229/leadership-now/can-innovation-actually-bemeasured.

[18] European Union, “Community Innovation Survey,” 2012. [Online]. Available: http://ec.europa. eu/eurostat/statistics-explained/index.php/Glossary:Community_innovation_survey_\%28CIS\% 29.

[19]M. Saunders, P. Lewis, and A. Thornhill, Research Methods for Business Students. (2009)

[20] J. Schumpeter, The theory of economic development: an inquiry into profits, capital, credit, interest, and the business cycle, vol. 46. (1934) 